\title{
Polyomavirus JCPyV infrequently detectable in adenoid cystic carcinoma of the oral cavity and the airways
}

\author{
Hanna Hämetoja ${ }^{1,2}$ • Jaana Hagström ${ }^{2,3}$ • Caj Haglund ${ }^{3,4}$ • Leif Bäck ${ }^{5}$ Antti Mäkitie ${ }^{5,6,7}$ - Stina Syrjänen ${ }^{1}$
}

Received: 29 March 2019 / Revised: 13 June 2019 / Accepted: 25 June 2019/Published online: 1 July 2019

(C) The Author(s) 2019

\begin{abstract}
Our objective was to assess the presence of three polyomaviruses, namely SV40, JCPyV, and BKPyV, and human papillomaviruses (HPV) in adenoid cystic carcinomas (ACC) of the minor salivary glands (MiSG) in the head and neck region. The study comprised 68 MiSG ACC patients operated during 1974-2012 at the Helsinki University Hospital (Helsinki, Finland). Medical records and 68 histological samples were reviewed. Polyomaviruses were detected with quantitative PCR and the DNA-positive samples were further analyzed for the presence of viral tumor T antigen (T-ag) with immunohistochemistry. HPV genotyping was performed with a Multiplex HPV Genotyping Kit. Only JCPyV DNA was found in ACC samples, being present in 7 (10.3\%) out of the 68 samples. The viral load of JCPyV was low varying between 1 to 226 copies/ng DNA. The JCPyV-positive samples originated from trachea (two samples), paranasal sinuses (one), and oral cavity (two). Additionally, JCPyV positivity was found in one lung metastasis of a tracheal tumor and one local disease failure of an oral cavity tumor. Three JCPyV DNA-positive samples showed weak nuclear staining for large T-ag. In conclusion, only JCPyV but not SV40, BKPyV, or HPV was found in ACC from the upper and lower airways. JCPyV copy numbers were low which might support its role as a "hit and run agent" in ACC carcinogenesis.
\end{abstract}

Keywords Adenoid cystic carcinoma $\cdot$ Polyomavirus $\cdot$ Oral cancer $\cdot$ Oncogenes $\cdot$ Human papillomavirus

Hanna Hämetoja

hanna.hametoja@helsinki.fi

1 Department of Oral Pathology, University of Turku and Turku University Hospital, Turku, Finland

2 Department of Pathology, University of Helsinki and Helsinki University Hospital, Helsinki, Finland

3 Research Programs Unit, Translational Cancer Biology Program, University of Helsinki, Helsinki, Finland

4 Department of Surgery, University of Helsinki and Helsinki University Hospital, Helsinki, Finland

5 Department of Otorhinolaryngology - Head and Neck Surgery, University of Helsinki and Helsinki University Hospital, Helsinki, Finland

6 Division of Ear, Nose and Throat Diseases, Department of Clinical Sciences, Intervention and Technology, Karolinska Institutet and Karolinska University Hospital, Stockholm, Sweden

7 Research Programme in Systems Oncology, Faculty of Medicine, University of Helsinki, Helsinki, Finland

\section{Introduction}

Adenoid cystic carcinoma (ACC) is a rare malignancy of glandular structures, which most commonly (70\%) appears in salivary glands [1]. Minor glands (MiSGs) are involved more often than major glands (MaSGs) [1,2]. Etiopathogenesis for $\mathrm{ACC}$ as well as for many other salivary gland tumors is still unknown. In ACC, genetic studies have found MYB/NFIB translocations and this fusion oncogene is overexpressed [3]. In addition, studies have provided evidence for Notch-pathway alterations in 11 to $29 \%$ of patients [4]. As the pathogenesis of ACC remains unknown, even viral background should be considered. Distinguished viral etiological factors among head and neck cancers are Epstein-Barr virus (EBV) in nasopharyngeal carcinoma and human papilloma virus (HPV) 16 in oropharyngeal squamous cell carcinoma $[5,6]$.

Furthermore, head and neck cancer studies have gained new knowledge on polyomaviruses (HPyVs) and their coinfection with other viruses [7-11]. A recent study on oncogenic DNA viruses in salivary gland tumors increases the interest on possible role of $\mathrm{HPyVs}$ in the pathogenesis of salivary gland tumors [12]. 
Currently, 13 human HPyVs have been identified [13, 14]. Among them, Merkel cell polyomavirus (MCPyV), BK polyomavirus (BKPyV), and JC polyomavirus (JCPyV) have been associated with human cancers [13]. MCPyV is classified as a grade $2 \mathrm{~A}$ carcinogen (probable carcinogen) by IARC while $\mathrm{BKPyV}$ and JCPyV are grade 2B carcinogens (possibly carcinogenic to humans) [13]. Simian vacuolating virus 40 (SV40) has an ability to cause cancer in animal models but clinical consequences to humans are controversial although SV40 contaminated polio vaccine was used during the years 1955-1963 $[13,15,16]$. HPyVs are small non-enveloped viruses consisting of circular double-stranded DNA genome $(5.2 \mathrm{~kb})$ that has two transcriptional units, early and late region [13]. The former encodes large $\mathrm{T}$ antigen (T-ag) (90-100 kDA nuclear protein) and the latter, small T-ag (17-22 kDa) viral capsid proteins VP1, VP2, and VP3 [13]. Large T-ag acts similarly as many other known oncoproteins of tumor viruses by interfering with tumor suppressor proteins $\mathrm{pRb}$ and $\mathrm{p} 53[8,11]$.

Roughly $80-90 \%$ of the population are latent carriers of $\mathrm{JCPyV}$ and BKPyV and primary infections are usually manifested subclinically during early childhood $[11,15,17]$. In healthy individuals, secretion of JCPyV and BKPyV might occasionally be detected in urine and saliva [18]. In the case of immunocompromised patients, however, polyomavirus reactivation may cause severe complications. These include polyomavirus-associated nephropathy due to BKPyV reactivation in kidney transplant recipients and JCPyV-related progressive multifocal leukoencephalopathy [15]. HPVs are widely studied and the causality of HPV type 16 and squamous cell carcinoma (SCC) has been classified as grade 1 (IARC vol 100, 2009) [19]. The etiological link between HPV and SCC has specially been shown in cancers of uterine cervix and oropharynx $[6,20]$. HPV has also been detected in salivary gland ACC although the connection between HPV and ACC does not seem to be strong [21-23]. According to the "hit and run theory," different viruses may contribute to tumorigenesis, for instance, polyomaviruses could augment the oncogenic properties of HPV during their co-infections [8].

Altogether, studies on HPyVs, HPVs, and salivary gland tumors are sparse and as far as we know, there are no previous publications on the presence of polyomaviruses in ACC. The aim of this study was to assess the prevalence of the three polyomaviruses, SV40, JCPyV, and BKPyV, and HPV in ACC samples of minor salivary and mucous glands.

\section{Materials and methods}

\section{Patient and tumor characteristics}

Table 1 summarizes the demographic data and tumor characteristics in a retrospective series on 68 patients with MiSG ACC. The patients were diagnosed and treated at the
Table 1 Characterization of the 68 patients with an adenoid cystic carcinoma of minor salivary and mucous glands

\begin{tabular}{|c|c|c|}
\hline & $N$ & $\%$ \\
\hline \multicolumn{3}{|l|}{ Sex } \\
\hline Male & 29 & 42.6 \\
\hline Female & 39 & 57.4 \\
\hline Female/male ratio & 1.35 & \\
\hline Median age, years (range) & $58(24-88)$ & \\
\hline \multicolumn{3}{|l|}{ Tumor site } \\
\hline Oral cavity & 41 & 60.3 \\
\hline Paranasal cavities & 6 & 8.8 \\
\hline Trachea & 6 & 8.8 \\
\hline Nasopharynx & 5 & 7.4 \\
\hline Oropharynx & 3 & 4.4 \\
\hline Ear & 4 & 5.9 \\
\hline Larynx & 2 & 2.9 \\
\hline Esophagus & 1 & 1.5 \\
\hline \multicolumn{3}{|l|}{$\mathrm{T}$ class } \\
\hline $\mathrm{T} 1$ & 18 & 26.5 \\
\hline $\mathrm{T} 2$ & 12 & 17.6 \\
\hline $\mathrm{T} 3$ & 6 & 8.8 \\
\hline $\mathrm{T} 4$ & 22 & 32.4 \\
\hline N/A & 4 & 5.9 \\
\hline \multicolumn{3}{|l|}{$\mathrm{N}$ class } \\
\hline N0 & 54 & 79.4 \\
\hline N1 & 1 & 1.5 \\
\hline $\mathrm{N} 2$ & 3 & 4.4 \\
\hline N/A & 4 & 5.9 \\
\hline \multicolumn{3}{|l|}{ Stage } \\
\hline I & 16 & 23.5 \\
\hline II & 12 & 17.6 \\
\hline III & 7 & 10.3 \\
\hline IV & 23 & 33.8 \\
\hline N/A & 4 & 5.9 \\
\hline
\end{tabular}

$N / A$, not available

TNM and stage classification for 62 tumors (trachea excluded)

Department of Otorhinolaryngology - Head and Neck Surgery, Helsinki University Hospital (Helsinki, Finland) between 1974 and 2012. The referral area for this tertiary care center currently is $1.6 \mathrm{M}$. The clinical data of this series have been characterized in our previous study [24] and the Ki67 immunostaining results collected from the same hospital data were now added. The tumor samples were re-evaluated and validated according to the diagnostic criteria by the classification of the World Health Organization classification (both 2005 and 2017) [3, 25]. The present tumor, node, metastasis (TNM) classification does not include tracheal tumors, and thus, the TNM classes on six $(8.8 \%)$ tracheal ACCs are not given. Additionally, in four cases (5.9\%), the TNM class could not be defined. 
Altogether, 68 paraffin blocks of tumor samples were available. Samples included 48 samples from primary tumors and 20 disease failures from 15 patients; altogether, we were able to study samples from 53 patients. In addition, ten normal salivary gland tissue samples from the same patients were used as normal controls.

The study comprised MiSG and mucous excreting gland samples from the head and neck area including trachea and esophagus. These gland types in the upper gastrointestinal tract and in the respiratory tract have similar structure and function. They maintain the overall moisturizing of the mucosa. MaSGs on the other hand are activated mainly during eating when they produce serous saliva. Due to the location of MiSGs, just beneath the epithelium, different carcinogenic agents and oncoviruses might have easier access to MiSGs compared with MaSGs.

Institutional Research Ethics Board approved the study concept (Dnro 31/13/03/02/2010, 01 February 2010) and Statistics Finland provided the dates and causes of death.

\section{DNA extraction}

\section{Formalin-fixed and paraffin-embedded biopsy samples}

DNA was extracted from 5 - $\mu \mathrm{m}$-thick deparaffinized sections $\left(1 \mathrm{~cm}^{2}\right.$ in total area) with the high salt method [26]. In brief, after deparaffinization, the sections were lysed in lysis buffer (10 mM Tris- $\mathrm{HCl}, 400 \mathrm{mM} \mathrm{NaCl}$, and 2 mM EDTA, pH 8.2) with proteinase $\mathrm{K}(200 \mu \mathrm{g} / \mathrm{mL})$ overnight at $+37^{\circ} \mathrm{C}$. After digestion, proteins were precipitated with saturated $\mathrm{NaCl}$ and the DNA with ethanol.

\section{HPV detection}

DNA was amplified with primer sets 1 and 2 from the Multiplex HPV Genotyping Kit ${ }^{\circledR}$ (DiaMex GmbH, Germany). Primer set 1 contains all HPV primers: nine biotinylated forward and three reverse primers for amplifying the HPV types under investigation. Primer set 2 (DNA quality control primers) contains primers for the amplification of a $\beta$-globin gene fragment to verify the amount and the quality of human genomic sample DNA. A negative control contained no genomic DNA to confirm the absence of a contamination in the amplification reactions. Multiplex HPV Genotyping Kit ${ }^{\circledR}$ detects the following 24 low risk (LR)- and high risk (HR) -HPV genotypes: LR-HPV6, 11, 42, 43, 44, and 70 and HR-HPV16, 18, 26, $31,33,35,39,45,51,52,53,56,58,59,66,68,73$, and 82 . The labeled hybrids were analyzed with a Luminex LX-100 analyzer (Bio-Plex 200 System, Bio-Rad Laboratories, Hercules, USA).

\section{Quantitative detection of SV40, JCPyV, and BKPyV}

Presence of SV40, JCPyV and BKPyV DNA in the samples was detected by quantitative polymerase chain reaction (qPCR) (Roche, Light Cycler 96) targeting their oncogenic large T-ag as described by McNees and coworkers, with slight modification [15]. RNase $\mathrm{P}$ was used as a reference gene (TaqMan ${ }^{\circledR}$ Copy Number Reference Assay RNase, Applied Biosystems, Foster City, CA, USA) to a relative expression of the target genes.

The primers and probes were designed as described earlier [15] and produced by Life Technologies as given in Table 2 . The probes for the target genes SV40, JCPyV, and BKPyV were labeled with 6-carboxyfluorescein (FAM) and (VIC) was used for labeling the probe for the reference gene RNase P. The qPCR reactions were performed in $20 \mu \mathrm{l}$ volume in micro titer plate. The following reaction conditions were used: $900 \mathrm{nM}$ of each primer and $100 \mathrm{nM}$ of their analogous probe, $10 \mu \mathrm{l}$ of TaqMan® Universal Mix II and $300 \mathrm{ng}$ template DNA. The detection of the reference gene TaqMan ${ }^{\circledR}$ RNase $\mathrm{P}$ (Applied Biosystems) was performed according to the manufacturer's recommendations. The conditions for all qPCR reactions were as follows: $2 \mathrm{~min}$ at $50^{\circ} \mathrm{C}, 10 \mathrm{~min}$ denaturation at $95{ }^{\circ} \mathrm{C}$ followed by 45 cycles of amplification with $95{ }^{\circ} \mathrm{C}$ denaturation for $15 \mathrm{~s}$, and annealing/extension at $60{ }^{\circ} \mathrm{C}$ for $60 \mathrm{~s}$. Amplification data measured as an increase in reporter fluorescence were collected in real time and analyzed by the Roche, Light Cycler 96 software.

The linear standard curves for JCPyV and BKPyV were obtained with a serial dilution of plasmids with amounts ranging from $1.2^{*} 10^{\wedge} 2 \mathrm{ng} / \mu \mathrm{l}$ to $1.2^{*} 10^{\wedge}-2 \mathrm{ng} / \mu \mathrm{l}$ for JCPyV and $9.5^{*} 10^{\wedge} 0$ to $9.5^{*} 10^{\wedge}-3 \mathrm{ng} / \mu \mathrm{l}$ for BKPyV. The standards for SV40 detection were constructed with a serial dilution of COS1 cell line DNA (which contains one copy of SV40/cell) with an amount range from $5.0^{*} 10^{\wedge} 4$ to $5.0^{*} 10^{\wedge} 0$ cells $/ \mu \mathrm{l}$, while the standards for the reference gene RNase $\mathrm{P}$ were acquired with a serial dilution of human placenta DNA extractions (Sigma-Aldrich, Darmstadt, Germany) ranging from $5.09 * 10^{\wedge} 2$ to $5.09 * 10^{\wedge}-2$. Cq values of less than 37 were considered positive. The copy numbers were calculated as copies in $1 \mu \mathrm{g}$ human DNA.

\section{Immunohistochemistry}

Immunohistochemistry was performed for JCPyV-positive samples only as BKPyV and SV40 remained qPCR negative. For immunohistochemistry, there are $4-\mu \mathrm{m}$-thick sections of formalin-fixed and paraffin-embedded blocks. The slides were deparaffinized in xylene and rehydrated in a series of ethanol solutions. Endogenous peroxidase activity was blocked by incubation of the slides with $3 \%$ hydrogen peroxide for $15 \mathrm{~min}$. Epitope retrieval was performed using boiling in $1 \mathrm{mM}$ citrate buffer, $\mathrm{pH} 6.0$ in the microwave for $5 \mathrm{~min}$, twice. 
Table 2 Primers and probes for SV40, JCPyV, and BKPyV

\begin{tabular}{ll}
\hline Name & Sequence detection \\
\hline SV40 primer forward & GAT GGC ATT TCT TCT GAG CAA A \\
SV40 primer reverse & GAA TGG GAG CAG TGG TGG AA \\
JCPyV primer forward & TTC TTC ATG GCA AAA CAG GTC TT \\
JCPyV primer reverse & GAA TGG GAA TCC TGG TGG AA \\
BKPyV primer forward & CTT TCT TTT TTT TTT GGG TGG TGT T \\
BKPyV primer reverse & TTG CCA GTG ATG AAG AAG CAA \\
SV40 T-ag probe 5'-FAM & CAG GTT TTC CTC ATTAAA \\
JCPyV T-ag probe 6 FAM & CCA CTT CTC ATT AAA TG \\
BKPyV T-ag probe 6 FAM & AGT GTT GAG AAT CTG C \\
\hline
\end{tabular}

Adapted from McNees et al. 2005
The primary antibody used was a mouse monoclonal antisimian virus T-ag that cross-reacts with JCPyV T-ag (AntiSV40 Antibody, clone Pab101, LifeSpan BioSciences Inc., Seattle WA, USA) and the dilution of 1:75 was used. The tissue was incubated with the primary antibody overnight, followed by detection with Dako REAL Detection System, Peroxidase/DAB+, Rabbit/Mouse, Dako, Glostrup, Denmark) and counterstained with hematoxylin.

\section{Results}

\section{The presence of JCPyV, BKPyV, SV40, and HPV in ACC} and in normal salivary gland tissue

All 68 samples remained negative for BKPyV, SV40, and HPV but seven of 68 (10.3\%) samples showed JCPyV DNA positivity. The characterization of the seven patients with JCPyV-positive ACC is given in Table 3. The viral load of JCPyV was low in all samples varying from 1 to 226

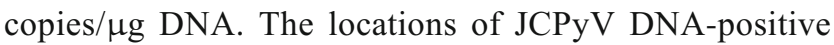
ACCs were as follows: two in the trachea, one in the lung metastasis of a tracheal tumor, one in the paranasal sinuses (stage IV tumor), two in the oral cavity (stage I and IV tumors), and one in local disease failure of an oral cavity tumor. All the normal salivary gland control tissues showed negativity to JCPyV, BKPyV, and SV40.

\section{Patients with JCPyV-positive ACC}

Table 3 shows the details of the seven patients with JCPyV DNA-positive ACC. The mean age of the patients with JCPyV DNA-positive tumor was 59 years (range, 43-80) and female to male ratio was 2.5 . In the whole cohort, the mean age was similar, 58 years (range, 24-88), but the female and male ratio was smaller, being 1.35. Among the JCPyVpositive ACCs, the most common growth pattern was cribriform $(42.8 \%)$, and the second was a combination of cribriform and tubular $(28.6 \%)$, followed by tubular $(14.3 \%)$, and combination of cribriform and solid (14.3\%), which simulates the pattern of the whole cohort [24]. Neural invasion (perineural, intraneural, or both) was present in three $(42.9 \%)$ out of the JCPyV-positive tumors and in $57.4 \%$ in the whole cohort. Proliferation index of Ki67 immunostaining varied from 4 to $35 \%$ (median 30\%) among the JCPyV-positive tumors and from 4 to $80 \%$ (median 30\%) in the whole cohort.

\section{Immunohistochemistry versus JCPyV DNA positivity}

In total, three out of the seven JCPyV DNA-positive tumor sections showed weak nuclear immunohistochemistry positivity for large T-ag as presented in Figs. 1 and 2. Copy numbers for two tracheal tumors and one oral cavity tumor were 1.11, 33.95, and 3.25/1 $\mu \mathrm{g}$ DNA, respectively. Immunopositivity had no association with the clinical outcome of the disease.

\section{Second primary tumors}

Of note is that some of the patients with JCPyV DNA-positive ACC suffered from other malignancies as well. One patient with a tracheal ACC with thyroid gland invasion was in addition diagnosed with a papillary microcarcinoma in the thyroid gland. The patient with an early stage I ACC in oral cavity died of SCC of the lungs soon after ACC treatment. Furthermore, the patient with ACC in paranasal sinuses had recovered from lymphoma 6 years earlier.

\section{Discussion}

Our present results show that JCPyV may be found in MiSG ACC samples by qPCR. However, the prevalence of JCPyV in ACC was low, i.e., only $10.3 \%$, and JCPyV presented with low copy numbers. Three out of the seven JCPyV-positive tumors were from the oral cavity while the rest were located in the upper and lower airways. As the number of JCPyVpositive cases was sparse and the viral loads were low, we can only speculate the possible viral role as an etiological 


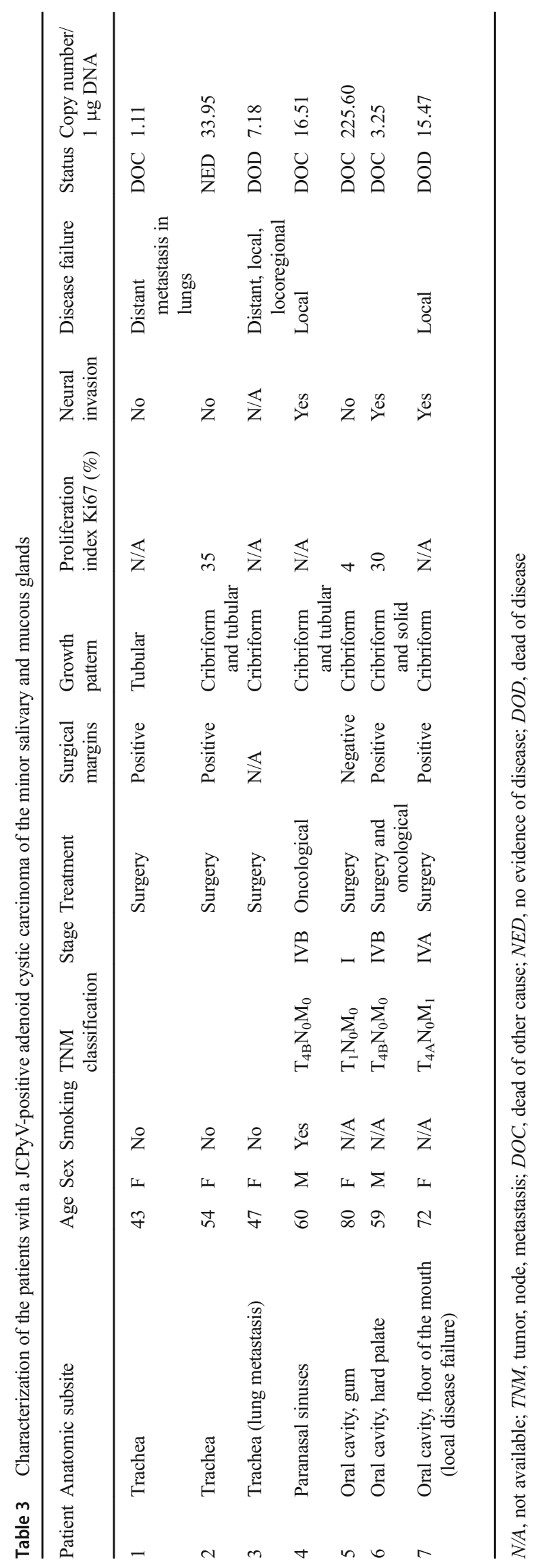




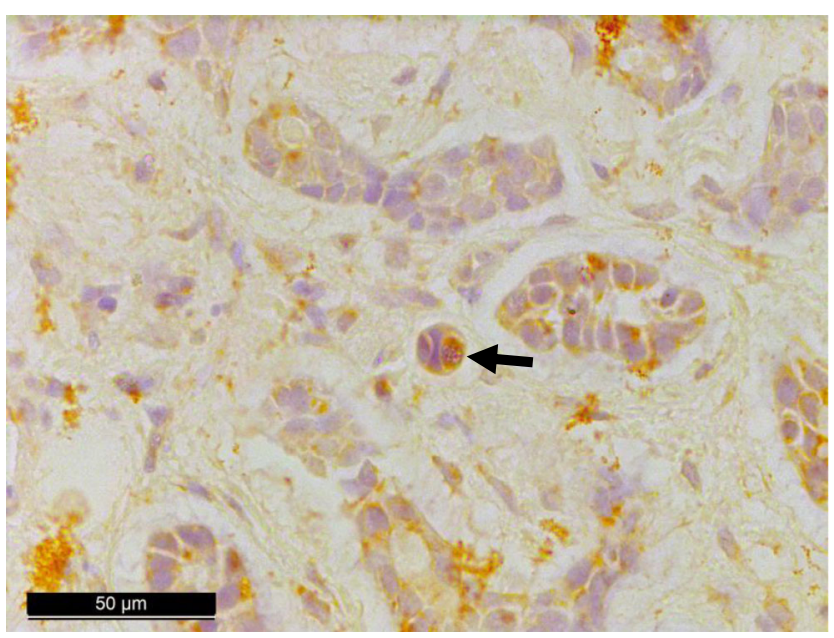

Fig. 1 Immunohistochemical staining for large $\mathrm{T}$ antigen showing JCPyV positivity in adenoid cystic carcinoma of the trachea (patient \#1 in Table 3)

factor for ACC. A "hit and run hypothesis" has been proposed for certain oncoviruses. Accordingly, this hypothesis claims that viruses can mediate cellular transformation through an initial "hit," while maintenance of the transformed state is compatible with the loss ("run") of viral molecules [27]. The low copy numbers in our study suggest the role of JCPyV in hit and run carcinogenesis model rather than as a continuous driver of the tumor formation. None of the HPyVs were detected in the normal salivary gland control tissue.

We were able to locate large T-ag on nuclei of the tumor cells by using SV40 antibody, which is cross-reacting with both JCPyV and BKPyV. qPCR technique is an accurate method for detecting HPyV DNA, but in the current study, immunohistochemical expression did not correlate well with qPCR findings, while only three out of the seven JCPyV-positive samples stained positively. Possible explanation for the negative staining might be that only few cells in the samples infected with JCPyV are transcriptionally and translationally

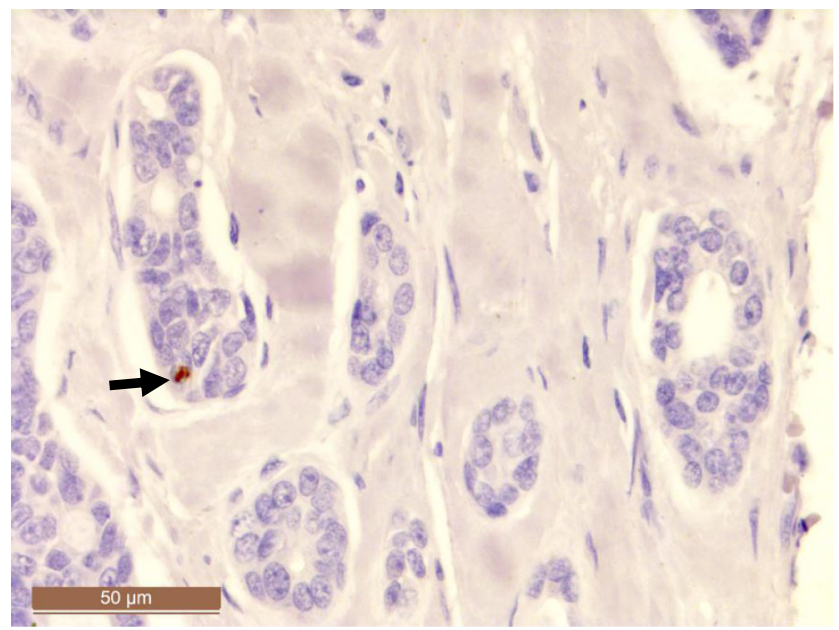

Fig. 2 Immunohistochemical staining positivity for large $\mathrm{T}$ antigen in adenoid cystic carcinoma of the trachea (patient \#2 in Table 3) active. According to the "hit and run theory," positive signals are detected only from sporadic cells (Figs. 1 and 2). Another possibility is that these approximately $7 \mu \mathrm{m}$ wide cells might have been cut out from the deeper sections prepared for immunohistochemistry.

The etiological risk factors for all salivary gland malignancies include exposure to nickel compounds and silica dust, employment at rubber manufacturing, hairdressers', and beauty shops, as well as irradiation, EBV, and HIV infection [10, 28, 29]. At molecular level, germline BRCA mutations and genetic variants in DNA double-strand brake repair genes have been related to the risk for salivary gland cancers including ACC [3].

As far as we know, there are no previous studies on the prevalence of JCPyV or other HPyVs in ACC. As discussed earlier, 80-90\% of population are latent carriers of JCPyV and $\mathrm{BKPyV}$ and HPyVs have been detected in saliva of healthy individuals, which strengthens the hypothesis of saliva being the transmission route for HPyVs $[11,15,17,18]$. Thus, the reservoir of HPyVs might be in salivary glands or in oral or oropharyngeal mucosa. An earlier experimental study showed that the injection of polyomavirus into salivary gland tissue of mice resulted in tumor formation resembling that of human pleomorphic adenoma [30]. Further, SV40 DNA has been identified in pleomorphic adenoma of parotid gland [31].

Overall, studies concerning HPyVs in head and neck cancers are rare [7, 9, 11, 32, 33]. Kutsuna et al. have linked high viral JCPyV load to oral SCC of the tongue, but they did not find any prognostic value for JCPyV [11]. Zheng et al. suggested that JCPyV could have an oncogenic role in the squamous cell carcinogenesis of tongue, pharynx, and larynx [32]. Contradictory to their findings, Polz-Gruszka et al. did not find JCPyV in any of the 62 oropharyngeal SCC in their series but found BKPyV in $17.7 \%$ of the tumor samples [7]. In these studies, viral DNA was detected by qPCR [7, 11, 32]. Some studies have reported negative $\mathrm{HPyV}$ results in head and neck cancer. Palmieri et al. did not detect SV40, BKPyV, or JCPyV DNA by qPCR evaluation in oral cavity SCC [9].

HPVs have been studied in ACC but the association does not seem to be strong [21-23]. However, recently, a new subtype of non-keratinizing SCC has been found in the sinonasal area having features of both ACC and SCC and being usually HPV type 33 positive $[3,34]$. This entity is named as HPVrelated multiphenotypic sinonasal carcinoma [3, 34]. In our study, HPV-positive ACCs were not detected.

Further studies are thus needed to understand the possible role of HPyV in the carcinogenesis of ACC.

\section{Conclusions}

Only JCPyV DNA but not SV40, BKPyV, or HPV was found in ACC from the upper and lower airways. JCPyV copy 
numbers were low which might support its role as a "hit and run agent" in ACC carcinogenesis.

Acknowledgments The authors thank the Department of Oral Pathology, Institute of Dentistry, University of Turku for providing the reagents.

Contributions $\mathrm{HH}$ and $\mathrm{JH}$ contributed to the study concept and design, data collection, histopathological analysis, interpretation of the results, and writing. $\mathrm{CH}$ contributed to the study concept and provided the laboratory facilities. LB and AM contributed to the study concept and design, and writing. SS contributed to the study concept and design, data collection, histopathological analysis, interpretation of the results and writing, and provided the laboratory facilities for qPCR. All the authors approved the publication.

Funding Open access funding provided by University of Turku (UTU) including Turku University Central Hospital. This work was supported by the Helsinki University Hospital Research Fund (TYH 2018215) and the Finska Läkaresällskapet.

\section{Compliance with ethical standards}

Institutional Research Ethics Board approved the study concept (Dnro 31/ 13/03/02/2010, 01 February 2010) and Statistics Finland provided the dates and causes of death.

Conflict of interest The authors declare that they have no conflict of interest.

Open Access This article is distributed under the terms of the Creative Commons Attribution 4.0 International License (http:// creativecommons.org/licenses/by/4.0/), which permits unrestricted use, distribution, and reproduction in any medium, provided you give appropriate credit to the original author(s) and the source, provide a link to the Creative Commons license, and indicate if changes were made.

\section{References}

1. DeAngelis AF, Tsui A, Wiesenfeld D, Chandu A (2011) Outcomes of patients with adenoid cystic carcinoma of the minor salivary glands. Int J Oral Maxillofac Surg 40:710-714. https://doi.org/10. 1016/j.ijom.2011.02.010

2. Bjorndal K, Krogdahl A, Therkildsen MH, Charabi B, Kristensen CA, Andersen E, Schytte S, Primdahl H, Johansen J, Pedersen HB, Andersen LJ, Godballe C (2015) Salivary adenoid cystic carcinoma in Denmark 1990-2005: outcome and independent prognostic factors including the benefit of radiotherapy. Results of the Danish Head and Neck Cancer Group (DAHANCA). Oral Oncol 51: 1138-1142. https://doi.org/10.1016/j.oraloncology.2015.10.002

3. El-Naggar AK, Chan JKC, Grandis JR, Takata T, Slootweg PJ (2017) WHO classification of head and neck tumours. IARCPress, Lyon France 15-17:164-165

4. Stephens PJ, Davies HR, Mitani Y, Van Loo P, Shlien A, Tarpey PS, Papaemmanuil E, Cheverton A, Bignell GR, Butler AP, Gamble J, Gamble S, Hardy C, Hinton J, Jia M, Jayakumar A, Jones D, Latimer C, McLaren S, McBride DJ, Menzies A, Mudie L, Maddison M, Raine K, Nik-Zainal S, O'Meara S, Teague JW, Varela I, Wedge DC, Whitmore I, Lippman SM, McDermott U, Stratton MR, Campbell PJ, El-Naggar AK, Futreal PA (2013)
Whole exome sequencing of adenoid cystic carcinoma. J Clin Invest 123:2965-2968. https://doi.org/10.1172/JCI67201

5. Mesri EA, Feitelson MA, Munger K (2014) Human viral oncogenesis: a cancer hallmarks analysis. Cell Host Microbe 15:266-282. https://doi.org/10.1016/j.chom.2014.02.011

6. Syrjanen S, Rautava J, Syrjanen K (2017) HPV in head and neck cancer-30 years of history. Recent Results Cancer Res. https://doi. org/10.1007/978-3-319-43580-0_1

7. Polz-Gruszka D, Morshed K, Jarzynski A, Polz-Dacewicz M (2015) Prevalence of Polyoma BK virus (BKPyV), Epstein-Barr virus (EBV) and Human Papilloma virus (HPV) in oropharyngeal cancer. Pol J Microbiol 64:323-328

8. Guidry JT, Scott RS (2016) The interaction between human papillomavirus and other viruses. Virus Res 231:139-147. https://doi. org/10.1016/j.virusres.2016.11.002

9. Palmieri A, Carinci F, Martinelli M, Spinelli G, Lo Muzio L, Rubini C, Scapoli L (2010) Absence of Simian virus 40, BK, and JC polyomavirus DNA in squamous cell carcinoma limited to the oral cavity. Head Neck 32(3):375-380. https://doi.org/10.1002/hed. 21197

10. Zheng W, Shu XO, Ji BT, Gao YT (1996) Diet and other risk factors for cancer of the salivary glands: a population-based case-control study. Int J Cancer 67:194-198

11. Kutsuna T, Zheng H, Abdel-Aziz HO, Murai Y, Tsuneyama K, Furuta I, Takano Y (2008) High JC virus load in tongue carcinomas may be a risk factor for tongue tumorigenesis. Virchows Arch 452: 405-410. https://doi.org/10.1007/s00428-007-0534-0

12. Chen AA, Gheit T, Stellin M, Lupato V, Spinato G, Fuson R, Menegaldo A, Mckay-Chopin S, Dal Cin E, Tirelli G, Da Mosto MC, Tommasino M, Boscolo-Rizzo P (2017) Oncogenic DNA viruses found in salivary gland tumors. Oral Oncol 75:106-110. https://doi.org/10.1016/j.oraloncology.2017.11.005

13. Burger-Calderon R, Webster-Cyriaque J (2015) Human BK polyomavirus-the potential for head and neck malignancy and disease. Cancers (Basel) 7:1244-1270. https://doi.org/10.3390/ cancers 7030835

14. Moens U, Rasheed K, Abdulsalam I, Sveinbjornsson B (2015) The role of Merkel cell polyomavirus and other human polyomaviruses in emerging hallmarks of cancer. Viruses. 7:1871-1901. https://doi. org/10.3390/v7041871

15. McNees AL, White ZS, Zanwar P, Vilchez RA, Butel JS (2005) Specific and quantitative detection of human polyomaviruses BKV, JCV, and SV40 by real time PCR. J Clin Virol 34:52-62. https://doi. org/10.1016/j.jcv.2004.12.018

16. Colvin EK, Weir C, Ikin RJ, Hudson AL (2014) SV40 TAg mouse models of cancer. Semin Cell Dev Biol 27:61-73. https://doi.org/ 10.1016/j.semcdb.2014.02.004

17. Burger-Calderon R, Madden V, Hallett RA, Gingerich AD, Nickeleit V, Webster-Cyriaque J (2014) Replication of oral BK virus in human salivary gland cells. J Virol 88:559-573. https:// doi.org/10.1128/JVI.02777-13

18. Robaina TF, Mendes GS, Benati FJ, Pena GA, Silva RC, Montes MA, Janini ME, Camara FP, Santos N (2013) Shedding of polyomavirus in the saliva of immunocompetent individuals. J Med Virol 85:144-148. https://doi.org/10.1002/jmv.23453

19. http://monographs.iarc.fr/ENG/Monographs/vol100B/mono100B. pdf. Accessed 01/18 2018

20. Mitra A, MacIntyre DA, Marchesi JR, Lee YS, Bennett PR, Kyrgiou M (2016) The vaginal microbiota, human papillomavirus infection and cervical intraepithelial neoplasia: what do we know and where are we going next? Microbiome. 4:58. https://doi.org/10. 1186/s40168-016-0203-0

21. Huhns M, Simm G, Erbersdobler A, Zimpfer A (2015) HPV infection, but not EBV or HHV-8 infection, is associated with salivary gland tumours. Biomed Res Int 2015:1-7. https://doi.org/10.1155/ 2015/829349 
22. Qian X, Kaufmann AM, Chen C, Tzamalis G, Hofmann VM, Keilholz U, Hummel M, Albers AE (2016) Prevalence and associated survival of high-risk HPV-related adenoid cystic carcinoma of the salivary glands. Int J Oncol 49:803-811. https://doi.org/10. 3892/ijo.2016.3563

23. Boland JM, McPhail ED, Garcia JJ, Lewis JE, Schembri-Wismayer DJ (2012) Detection of human papilloma virus and p16 expression in high-grade adenoid cystic carcinoma of the head and neck. Mod Pathol 25:529-536. https://doi.org/10.1038/modpathol.2011.186

24. Hametoja H, Hirvonen K, Hagstrom J, Leivo I, Saarilahti K, Apajalahti S, Haglund C, Makitie A, Back L (2017) Early stage minor salivary gland adenoid cystic carcinoma has favourable prognosis. Virchows Arch 471:785-792. https://doi.org/10.1007/ s00428-017-2163-6

25. Barnes L, Eveson WJ, Reichart P, Sidransky D (2005) Pathology and genetics of head and neck tumours, 4th edn. IARCPress, Lyon France, pp 221-222

26. Miller SA, Dykes DD, Polesky HF (1988) A simple salting out procedure for extracting DNA from human nucleated cells. Nucleic Acids Res 16:1215

27. Nevels M, Tauber B, Spruss T, Wolf H, Dobner T (2001) "Hit-andrun" transformation by adenovirus oncogenes. J Virol 75:30893094. https://doi.org/10.1128/JVI.75.7.3089-3094.2001

28. Guzzo M, Locati LD, Prott FJ, Gatta G, McGurk M, Licitra L (2010) Major and minor salivary gland tumors. Crit Rev Oncol Hematol 74:134-148. https://doi.org/10.1016/j.critrevonc.2009. 10.004

29. Kim D, Hwang YI, Choi S, Park C, Lee N, Kim EA (2013) A case of tracheal adenoid cystic carcinoma in a worker exposed to rubber fumes. Ann Occup Environ Med 25:22. https://doi.org/10.1186/ 2052-4374-25-22

30. Dawe CJ, Freund R, Mandel G, Ballmer-Hofer K, Talmage DA, Benjamin TL (1987) Variations in polyoma virus genotype in relation to tumor induction in mice. Characterization of wild type strains with widely differing tumor profiles. Am J Pathol 127: 243-261

31. Martinelli M, Martini F, Rinaldi E, Caramanico L, Magri E, Grandi E, Carinci F, Pastore A, Tognon M (2002) Simian virus 40 sequences and expression of the viral large $\mathrm{T}$ antigen oncoprotein in human pleomorphic adenomas of parotid glands. Am J Pathol 161: $1127-1133$

32. Zheng Y, Xia P, Zheng HC, Takahashi H, Masuda S, Takano Y (2010) The screening of viral risk factors in tongue and pharyngolaryngeal squamous carcinoma. Anticancer Res 30: 1233-1238

33. Mazzoni E, Martini F, Corallini A, Taronna A, Barbanti-Brodano G, Querzoli P, Magri E, Rotondo JC, Dolcetti R, Vaccher E, Tognon M (2016) Serologic investigation of undifferentiated nasopharyngeal carcinoma and simian virus 40 infection. Head Neck 38:232236. https://doi.org/10.1002/hed.23879

34. Bishop JA, Westra WH (2018) Human papillomavirus-related multiphenotypic sinonasal carcinoma: an emerging tumor type with a unique microscopic appearance and a paradoxical clinical behaviour. Oral Oncol 87:17-20. https://doi.org/10.1016/j.oraloncology. 2018.10.011

Publisher's note Springer Nature remains neutral with regard to jurisdictional claims in published maps and institutional affiliations. 